\title{
Investigation of adolescents' physical education trait anxiety levels by a range of variables
}

\author{
Yaprak Kalemoglu-Varol, Mustafa Kayihan Erbas \\ Department of Physical Education and Sport, Aksaray University, Aksaray, Turkey
}

Email address:

yaprak81@gmail.com (Y. Kalemoglu-Varol)

\section{To cite this article:}

Yaprak Kalemoglu-Varol, Mustafa Kayihan Erbas. Investigation of Adolescents' Physical Education Trait Anxiety Levels by a Range of Variables. American Journal of Sports Science. Vol. 3, No. 1, 2015, pp. 1-5. doi: 10.11648/j.ajss.20150301.11

\begin{abstract}
The aim of this study is to determine adolescents' trait anxiety levels during physical education lessons and investigate them by a range of variables. Screening model was used in the study. The study group was a total of 1083 high school students $\left(M_{\mathrm{age}}=16.08, \mathrm{SD}=1.11\right)$, including 491 females $(45.3 \%)$ and 592 males (\%54.7), from high schools in the provinces of Ankara, Aksaray and Istanbul during the academic year 2013-2014. "Physical Education Trait Anxiety Scale" was used to collect data. In the analyses, in addition to descriptive statistics, independent sample t-test of the difference between the arithmetic means and one-way analysis of variance were used. In the study, students were found to have a moderate level of physical education trait anxiety. Significant differences were observed by gender and grade in physical education trait anxiety levels, while no significant difference was found by being licensed athlete.
\end{abstract}

Keywords: Attitude, Anxiety, Trait Anxiety, Adolescent, Physical Education Lesson

\section{Introduction}

Anxiety is one of the most studied topics in psychology as well as education and sports [1]. Researchers have studied factors associated with anxiety for many years and in the end developed some theories that can explain and treat this structure. According to Hembree [2], anxiety comprises a multi-dimensional structure and is a state where substructures associated with different states emerge. Lewis (1970) explains the concept of structure referred to in this definition as an expression of feelings generally supported by fear and shock (cited from Hembree, 1990) [2]. Anxiety arising from genetic and biological factors, learning, experiences and stimulus in the living environment [3] has been described by Spielberger in two ways: trait anxiety and state anxiety [4]. State anxiety is an emotional reaction caused by people interpreting special states as threatening [3]. Trait anxiety is described as a predisposition to perceive certain situations as threatening and to respond to these situations with increased state anxiety (Martens, Vealey and Burton, 1990 cited from Spielberger, 1966) [5].

Learning is a process associated with several factors. According to Phillips [6], anxiety is one of the important factors that affect this process. Seven and Engin [7] stated that very low and very high anxiety levels make learning difficult, whereas a moderate level of anxiety facilitates and encourages learning. Physical education course has an important place in achieving objectives of education, and Pate et al. described it as a form of active life containing physical continuity which is performed to ensure a fun participation in students' development, knowledge, attitudes, motor and behavioral skills through physical activity in school programs [8]. Although physical education course is a fun course in general among students, it may be perceived as a difficult subject to learn and practice by many students. Although studies typically investigate positive affective experiences, including enjoying physical education lessons [9], anxiety during physical education lessons is an important determinant of performance and performance-related cognitions such as achievement goals, effort and learning strategies [10]. In the literature, in studies related to physical education and anxiety about sports, mostly, anxiety levels of students or athletes non-specific to a course or competitive anxieties of athletes were investigated $[11,12,13,14]$. In some studies related to anxiety, the effects of various physical education and sports activities in reducing anxiety levels in children and adolescents were also examined [15]. However, it was thought that it will be important to determine anxiety levels of students during lessons of physical education, which is different from other areas of education in terms of content and teaching methods. Because studies show that as students reach 
adolescence, their participation in physical activities and physical education lessons diminish [16, 17]. One of the possible causes of this was thought to be trait anxiety developed for physical education lesson. Because such anxiety in students can be reflected as reluctance and timidity against physical education lessons.

Studies on anxiety show that this feeling is also influenced by many variables. Age is one of the most important factors affecting anxiety. Anxiety is one of the most frequently experienced emotions during adolescence [18]. Anxiety level deviates according to the developmental periods and fluctuations can be seen in anxiety level from kindergarten to adolescence [19]. According to psychologists, anxiety is a mental and somatic indicator of an individual's perceptions against emotional and physical states, and it is most intensively experienced for two years after birth and during puberty [20]. Anxiety significantly affects physical development, mental structures and behavioral characteristics of adolescents during middle and late adolescence (14-19 years), which corresponds to high school age $[21,22]$. Accordingly, adolescence stands out as significant years in terms of anxiety levels during adolescence.

When studies related to anxiety in the field of physical education were examined, there was no study which aims to determine trait anxiety level towards physical education lessons. It is thought that trait anxiety levels of adolescents toward physical education lesson differ according to the gender, grade and being licensed athlete. If anxiety levels differ from these variables, more concrete proposals can be made to reduce level of anxiety towards physical education. Because reduced level of anxiety towards physical education course is important to get maximum benefit from physical education lessons, which play an important part in achieving the objectives of education. Hence, the aim of the present study was to investigate adolescents' trait anxiety levels during physical education lessons by variables including gender, being a licensed athlete and grade.

\section{Methods}

\subsection{Participants and Procedure}

Table 1. Descriptive statistics of the study group

\begin{tabular}{llcc}
\hline Variables & & Noun & \% \\
\hline \multirow{2}{*}{ Gender } & Female & 491 & 45.3 \\
& Male & 592 & 54.7 \\
& $9^{\text {th }}$ & 298 & 27.5 \\
Grade & $10^{\text {th }}$ & 370 & 34.2 \\
& $11^{\text {th }}$ & 266 & 24.6 \\
& $12^{\text {th }}$ & 149 & 13.8 \\
Registered Athlete & Yes & 682 & 63.0 \\
& No & 401 & 37.0 \\
\hline
\end{tabular}

The study group was 1083 high school students $\left(M_{\text {age }}=\right.$ 16.08, $\mathrm{SD}=1.11)$, who were selected through random sampling, from various high schools in the provinces of Ankara, Aksaray and Istanbul during the academic year 2013-2014. The procedure took about 10 minutes. 74 of 1157 questionnaires obtained after the procedure were excluded from the study due to the fact that some of the questions were left blank or two different answers were given and 1083 questionnaires were considered valid. Descriptive statistics of the study group are given in Table 1 .

\subsection{Data Collection Tools}

Personal information form and "Physical Education Trait Anxiety Scale" were used as data collection tools.

\subsubsection{Personal Information Form}

This form includes items questioning respondents about their gender, grade and whether the respondent is a registered athlete.

\subsubsection{Physical Education Trait Anxiety Inventory}

"Physical Education Trait Anxiety Scale" developed by Barkoukis, Rodafinos, Koidou and Tsorbatzoudis [1] was adapted to Turkish by Kalemoğlu-Varol [23]. As in the original scale, the 18-item scale is composed of three subscales, namely "Cognitive Processes (CP)", "Somatic Anxiety (SA)" and "Worry (W)". Each subscale contains 6 items. The scale is a 5-point Likert-type scale, rated using (1) I strongly disagree to (5) I strongly agree. All items in the scale are positive expressions and high scores refer to high anxiety levels. The scale showed high internal consistency and test-retest reliability. Cronbach's alpha coefficients for internal consistency were .93 for cognitive processes subscale, .97 for somatic anxiety subscale, .98 for worry subscale, and .94 for the entire scale. The test-retest reliability coefficient of the scale was .96. Higher compliance values obtained as a result confirmatory factor analysis showed that 3-subscale structure of the scale was validated (RMSEA $=0.064, \mathrm{NFI}=0.97$, $\mathrm{NNFI}=0.98, \quad \mathrm{CFI}=0.99, \quad \mathrm{SRMR}=0.033, \quad \mathrm{GFI}=0.88$ and $\mathrm{AGFI}=0.84$ ).

At the end of the internal-consistency analysis performed in this study, the Cronbach Alpha values were calculated as .91 for the whole scale, .81 for the "CP" subscale, .82 for the "SA" subscale and .82 for the "W" subscale.

\subsection{Data Analysis}

In the study, first, mean values of the items in each subscale were calculated and thus the score for that subscale was determined. In data analysis were carried out through these factor scores. In the analysis of data; descriptive statistics (number, percentage, mean and standard deviation) and independent samples t-test and One-way analysis of variance (One-Way-ANOVA) for identifying any difference between dependent and independent variables were utilized. In the one-way analysis of variance (ANOVA), Tukey HSD post-hoc test was performed in order to find between which groups inter-unit differences are. Significance levels of 0.01 and 0.05 were used in the interpretation of data. The research data were analyzed by SPSS 18 software. 


\section{Results}

Students were found to have a moderate level of trait anxiety towards physical education course $\left(M_{\text {anxiety }}=39.15\right.$, $\mathrm{SD}=13.61)$.

\subsection{Trait Anxiety Level by Gender}

Analysis results on students' physical education lesson trait anxiety by gender are given in Table 2 .

Table 2. Trait anxiety level by gender

\begin{tabular}{lccccc}
\hline Dimension & Gender & Noun & Mean & SD & P \\
\hline \multirow{2}{*}{ CP } & Female & 491 & 13.42 & 4.786 & \multirow{2}{*}{$.000^{*}$} \\
& Male & 592 & 12.23 & 5.182 & \\
SA & Female & 491 & 13.13 & 5.980 & \multirow{2}{*}{$010^{*}$} \\
& Male & 592 & 12.18 & 6.067 & \\
W & Female & 491 & 14.64 & 5.593 & \multirow{2}{*}{$006^{*}$} \\
& Male & 592 & 13.68 & 5.712 & \\
Total & Female & 491 & 41.05 & 12.955 & $.000 *$ \\
& Male & 592 & 37.58 & 13.947 & \\
\hline
\end{tabular}

$* \mathrm{p}<0.05$

When Table 2 is examined; it is clear that female students' mean trait anxiety scores were higher than male students in total score for physical education trait anxiety scale $\left.M_{\text {males }}=37.58 ; M_{\text {females }}=41.05\right)$ and in "cognitive processes" $\left(M_{\text {males }}=12.23 ; \quad M_{\text {females }}=13.42\right), \quad$ "somatic anxiety" $\left(M_{\text {males }}=12.18 ; \quad M_{\text {females }}=13.13\right)$ and worry $\left(M_{\text {males }}=13.68\right.$; $\left.M_{\text {females }}=14.64\right)$ subscales $(\mathrm{p}<0.05)$.

\subsection{Trait Anxiety Level by being Licensed Athlete}

Analysis results of students' physical education trait anxiety by whether the respective student is a licensed athlete (LA) are given in Table 3.

In view of Table 3; no significant difference was observed in total score for physical education trait anxiety scale $\left(M_{\text {yes }}=39.05 ; \quad M_{\text {no }}=39.33\right)$ and "cognitive processes" $\left(M_{\mathrm{yes}}=12.75 ; M_{\mathrm{no}}=12.81\right)$ and worry $\left(M_{\mathrm{yes}}=13.86 ; \mathrm{M}_{\mathrm{no}}=14.54\right)$ subscales by whether the respective student is a registered athlete. , whereas in somatic anxiety subscale $\left(M_{\text {yes }}=13.04\right.$; $\left.M_{\mathrm{no}}=11.88\right)$, a significant difference was observed by whether the respective student is a licensed athlete.

Table 3. Trait anxiety level by whether the respective student is a licensed athlete (LA)

\begin{tabular}{lccccc}
\hline Dimension & LA & Noun & Mean & SD & P \\
\hline \multirow{2}{*}{ CP } & Yes & 682 & 12.75 & 4.941 & \\
& No & 401 & 12.81 & 5.209 & .836 \\
SA & Yes & 682 & 13.04 & 6.284 & \\
& No & 401 & 11.88 & 5.543 & $.002 *$ \\
W & Yes & 682 & 13.86 & 5.386 & \\
& No & 401 & 14.54 & 6.122 & .057 \\
\multirow{2}{*}{ Total } & Yes & 682 & 39.05 & 13.402 & .744 \\
& No & 401 & 39.33 & 13.973 & \\
\hline
\end{tabular}

$* \mathrm{p}<0.05$

\subsection{Trait anxiety Level by Grade}

Analysis results on students' physical education lesson trait anxiety by grade $(\mathrm{G})$ variable are shown in Table 4 .

Table 4. Trait anxiety level by grade variable

\begin{tabular}{|c|c|c|c|c|c|c|c|}
\hline Dimension & Grade & Noun & Mean & SD & $\mathbf{F}$ & $\mathbf{p}$ & Tukey HSD \\
\hline \multirow{4}{*}{$\mathrm{CP}$} & 9 & 298 & 12.49 & 4.792 & \multirow{4}{*}{1.171} & \multirow{4}{*}{.320} & \\
\hline & 10 & 370 & 13.05 & 5.357 & & & \\
\hline & 11 & 166 & 12.50 & 4.936 & & & \\
\hline & 12 & 149 & 13.11 & 4.877 & & & \\
\hline \multirow{4}{*}{ SA } & 9 & 298 & 12.35 & 6.010 & \multirow{4}{*}{4.775} & \multirow{4}{*}{$.003 *$} & $9<12$ \\
\hline & 10 & 370 & 12.04 & 5.438 & & & $10<12$ \\
\hline & 11 & 166 & 12.82 & 6.027 & & & \\
\hline & 12 & 149 & 14.18 & 7.231 & & & \\
\hline \multirow{4}{*}{ W } & 9 & 298 & 14.35 & 5.716 & \multirow{4}{*}{.473} & \multirow{4}{*}{.701} & \\
\hline & 10 & 370 & 14.19 & 5.905 & & & \\
\hline & 11 & 166 & 13.81 & 5.513 & & & \\
\hline & 12 & 149 & 13.97 & 5.322 & & & \\
\hline \multirow{4}{*}{ Total } & 9 & 298 & 39.11 & 13.460 & \multirow{4}{*}{.481} & \multirow{4}{*}{.696} & \\
\hline & 10 & 370 & 39.29 & 13.870 & & & \\
\hline & 11 & 166 & 38.46 & 13.641 & & & \\
\hline & 12 & 149 & 40.10 & 13.268 & & & \\
\hline
\end{tabular}

$* \mathrm{p}<0.05$

When Table 4 is examined, significant differences by grade variable were identified in somatic anxiety subscale of physical education trait anxiety scale. Accordingly; mean scores of $9^{\text {th }}$ and $10^{\text {th }}$ graders $\left(M_{\text {nine }}=12.35 ; M_{\text {ten }}=12.04\right)$ were lower than that of $12^{\text {th }}$ graders $(M=14.18)$. However, there was no significant difference by grade variable in total score for physical education trait anxiety scale and cognitive processes and worry subscales $(\mathrm{p}>.05)$.

\section{Discussion}

In this study, high school students were found to have a moderate level of physical education trait anxiety. Since adolescence is a period when most intense anxiety is 
experienced [20], it is expected that adolescents generally have high anxiety. In a study conducted with final-year high school students, approximately $2 / 3$ rds of the study group was reported to have a trait anxiety level above the threshold [24]. In another study which investigated high school students' trait anxiety levels, it was established that adolescence has the highest trait anxiety scores, early adulthood the lowest and middle age group is in second place. High trait anxiety scores during adolescence were associated with adolescent problems and test anxiety [20]. In adolescents, anxiety markedly affects their physical development, mental structure and behavior characteristics [21,22]. Particularly during lessons of physical education, which is based on physical movements, timid and shy attitudes can be seen in adolescents' participation in physical activities due to rapid physical growth and sex development [25], and this is thought to be the cause of trait anxiety towards the course. Indeed, as stated by Shephard and Trudeau [26] and Tremayne [27], physical education lesson is a lesson during which the focus is on physical skills and these physical skills and assessments take place before peers, which may lead to the fact that students worry about appearing inept against their peers, failure, injury, their body structure and image. Especially the decline in participation in physical education lessons during high school years $[16,17]$ was thought to be a result of trait anxiety developed against this course, which we can generally rate as a fun and popular course.

When students' physical education trait anxiety levels are examined by gender variable (Table 2), female students were found to have higher mean scores for physical education trait anxiety scale as well as higher mean scores in cognitive process, somatic anxiety and worry subscales than male students. When respective work on determination of anxiety level in physical activities and competitive anxiety and other fields are investigated, studies which are in line with the finding of this study [28,29] were found. The idea that females are more anxious than males is not a new idea. Kierkegaard [30] suggested that women are more anxious than men, and that this essentially stems from the fact that women have a spiritual nature, not from physical weakness of women, that anxiety increases with increasing spirituality. With regard to physical education and sports activities, girls have a more delicate and reserved nature physically than boys so it is generally expected that girls have higher physical education trait anxiety levels as compared to boys. However, considering the high number of studies which are inconsistent with the findings of this study, lots of further work needs to be conducted in order to determine whether physical education trait anxiety differs by gender.

There was no significant difference by whether the respective students are a registered athlete in total scores for physical education trait anxiety scale and in cognitive process and worry subscales (Table 3 ). In somatic anxiety subscale, students who are registered athletes were found to have higher anxiety levels than students who are not registered athletes. Statements in somatic anxiety subscale of physical education trait anxiety scale are intended to measure students' concerns about their own bodies in general (e.g. I feel my body aches while making the movements during physical education lessons; I feel like being strangled during physical education lessons, I feel like I'm having difficulty breathing during physical education lessons). Students engaged in sports as a registered athlete are expected to have less anxiety in general. However, the reason for this finding can be the fact that training level of registered athletes is higher than other students and hence they are anxious about not being able to fulfill teachers' expectations of success from them.

There was no significant difference by grade variable in total scores for physical education trait anxiety scale and cognitive processes and worry subscales (Table 4). In somatic anxiety subscale, mean scores of $9^{\text {th }}$ and $10^{\text {th }}$ graders were found to be higher than that of $12^{\text {th }}$ graders. In a study conducted with $12^{\text {th }}$ graders, approximately $2 / 3$ rds of the study group was reported to have a trait anxiety level above the threshold [24]. Final year students enter a period of tests with high stress level with a desire to be able to continue their education in universities, the next level in education. In this process, the increase in adverse effects of psychologically and physiologically intense and exhausting work schedule can be one of the causes which may increase somatic anxiety level in this age group. However, particularly high school seniors' efforts to become aware of their responsibilities for life and be on their own by leaving protection of their parents can be one of possible reasons for the increase in their somatic anxiety levels. In sum, this can be a result of the increase in age-dependent expectations from life, better awareness of facts and the increase in responsibilities.

However, generalization of the results of this study, which is thought to contribute to the field, is limited by the fact that the study was conducted with a selected group of adolescents in city centers of only three provinces and that the study group was relatively small. The study was the first study on determination of adolescents' trait anxiety levels during physical education lessons by a range of variables so it is thought to provide guidance to further studies in this field. Therefore, similar studies to be conducted with a variety of samples are required. It is considered that such studies will be helpful for gaining better insight into adolescents' physical education trait anxiety levels, and into states affecting them.

\section{References}

[1] Barkoukis, V., Rodafinos, A., Koidou, E., \& Tsorbatzoudis, H. (2012). Development of a scale measuring trait anxiety in physical education. Measurement in Physical Education and Exercise Science. 16:4, 237-253.

[2] Hembree, R. (1990). The nature, effect and relief of mathematics anxiety. Journal of Research in Mathematics Education. 21(1), 33-46.

[3] Kutlu, Ö. (2001). Ergenlerin üniversite sınavlarına ilişkin kaygıları. Eğitim ve Bilim, 26(121).

[4] Cheng, C., \& Cheung, M.W.L. (2005). Psychological responses to outbreak of severe acute respiratory syndrome: A prospective, multiple time-point study, Journal of Personality. $73: 1,261-285$. 
[5] Martens, R., Vealey, R., \& Burton, D. (1990). Competitive Anxiety in Sport. Champaign, IL: Human Kinetics.

[6] Phillips, D. (1984). The illusion of incompetence among academically component children. Child Development, 55 (6), 2000-2016

[7] Seven, M.A., \& Engin, A.O. (2008). Öğrenmeyi etkileyen faktörler. Atatürk Üniversitesi Sosyal Bilimler Enstitüsü Dergisi, 12(2), 189-212.

[8] Pate, R., Corbin, C., \& Pangrazi, B. (1998). Physical activity for young people. The President's Council on Physical Fitness and Sports Research Diegest. 3(3), 1-6.

[9] Barr-Anderson, D.J., Neumark-Sztainer, D., Schmitz, K.H., Ward, D.S., Conway, T.L., Pratt, C., Baggett, C.D., Lytle, L., \& Pate, R.R. (2008). But I like PE: Factors associated with enjoyment of physical education class in middle school girls. Research Quarterly for Exercise and Sport. 79, 18-27.

[10] Cury, F., Da Fonseca, D., Rufo, M., Peres, C., \& Sarrazin, P. (2003). The trichotomous model and investment in learning to prepare for a sport test: A mediational analysis. British Journal of Educational Psyshology, 73, 529-543.

[11] Ariza-Vargas, L., Dominguez-Escribano, M., Lopez-Bedoya, J., \& Vernetta-Santana, M. (2011). The effect of anxiety on the ability to learn gymnastic skills: A study based on the schema theory. The Sport Psychologist. 25, 127-143.

[12] Chamanabadi, G.E., Pooladiborj, H., Esmaeili, B., \& Zamani, M.T. (2012). A study of the effect of an aerobic training program on the level of trait anxiety in high school students of khauf county. European Journal of Experimental Biology, 2(4), 1103-1105.

[13] K.meswania, N. (2012). A study of anxiety level in selected players of various schools sports and non-players. International Global Research Analysis. 1(4), 65-66.

[14] Selmi, H., Selmi, W., \& Hermassi, S. (2013). Sportivisation impact of physical education on state anxiety and mood states of secondary students. International Journal of Scientific and Research Publications, 3(8), 1-6.

[15] Dalkıran, O., \& Tuncel, F. (2007). Ortaöğretim kurumlarında beden eğitimi dersinin seçmeli ders olarak işlenmesinin öğrenciler gözüyle değerlendirilmesi. Spormetre, 5(1), 37-42.

[16] Ntoumanis, N., Barkoukis, V., \& Thogersen-Ntoumani, C. (2009). Developmental trajectories of motivation in physical education: Course, demographic differences and antecedents. Journal of Educational Psychology, 101, 717-728.

[17] Sallis, J.F., Prochaska, J.J., \& Taylor, W.C. (2000). A review of correlates of physical activity of children and adolescents. Medicine \& Science in Sports \& Exercise, 32(5), 963-975.
[18] Tahiroğlu, A.Y., Avcı, A., \& Çekin, N. (2008). Çocuk istismarı, ruh sağllğı ve adli bildirim zorunluluğu, Anadolu Psikiyatri Dergisi, 9(1), 1-7.

[19] Duchesne, S., Vitaro, F., Larose, S., \& Tremblay, R.E. (2008). Trajectories of anxiety during elementary-school years and the prediction of high school noncompletion, Journal of Youth and Adolescence, 37(9), 1134-1146.

[20] Kartopu, S. (2012). Lise öğrenci ve öğretmenlerinin durumluk ve sürekli kaygı düzeylerinin bazı değişkenler açısından incelenmesi (Kahramanmaraş Örneği). İlahiyat Fakültesi Dergisi, 17:2, 147-170.

[21] Gül Çelik, G. (2007). Çocuk ve Ergen Ruh Sağlığı ve Hastalıkları Kliniğine Başvuran Ergenlerin Özellikleri, Uzmanlık Tezi, Çukurova Üniversitesi Tıp Fakültesi, Çocuk Ruh Sağlığı ve Hastalıkları Anabilim Dalı, Adana.

[22] Lewis, M., Vitulano, L.A. (2003). Biopsychosocial 1ssues and risk factors in the family when the child has a chronic illness. Child Adolesc Psychiatr Clin N Am, 12:389-399.

[23] Kalemoğlu Varol, Y. (2014). Turkish adaptation of the physical education trait anxiety scale: The validity and reliability study. International Journal of Human Sciences, 11(1), 221-235.

[24] Ceylan, A., Özen, S.., Palancı, Y., Saka, G., Aydın, Y.E., Kıvrak, Y., \& Tangolar, Ö. (2003). Lise son sinıf öğrencilerinde anksiyete-depresyon düzeyleri ve zararlı alışkanlıklar: Mardin çalışması. Anadolu Psikiyatri Dergisi, 4, 144-114.

[25] Tamer, K., \& Pulur, A. (2001). Beden Eğitimi ve Sporda Öğretim Yöntemleri. Ankara: Kozan Ofset.

[26] Shephard, R.J. \& Trudeau, F. (2000). The legacy of physical education: Influences on adult lifestyle. Pediatric Exercise Science. 12, 34-50.

[27] Tremayne, P. (1995). Children and sport psychology. In T. Morris \& J. Sunders (Eds.), Sport Psychology: Theory, applications and issues. Chichester: Wiley. Pp. 516-537.

[28] Ginsburg, G.S., \& Silverman, W.K. (2000). Gender role orientation and fearfulness in children with anxiety disorders. The Journal of Anxiety Disorders, 14, 57-67.

[29] Dönmez, K.H. (2013). Analysis of state anxiety and trait anxiety levels of athletes attending inter-unıversities basketball compeition held in Samsun. International Journal of Social Science, 6(5), 243-248.

[30] Kierkegaard, S. (2009). Kaygı Kavramı (Translation: T. Armaner), İstanbul: Türkiye İș Bankası Kültür Yayınları. 